\section{Fotografía y memoria visual de la dictadura militar. Reflexiones desde la historia}

Photography and visual memoirs of military dictatorship. Reflections from history

\author{
Fernando Camacho-Padilla \\ LAURA Ramírez-PALACIO*
}

\section{Resumen}

La demanda social que prevalece en Chile sobre la recuperación de la memoria de los acontecimientos más sensibles vividos en el país durante los años del régimen militar (19731990) ha tenido como resultado la publicación de varios libros de fotografías sacadas durante los últimos años. Por esta razón, actualmente se dispone de un número significativo de fotografías documentales, las cuales ilustran las prácticas represivas cometidas por las fuerzas de seguridad. Las imágenes fueron

Departamento de Historia Contemporánea, Universidad Autónoma de Madrid, fernando.camacho@uam.es; Doctoranda en Estudios Artísticos, Literarios y de la Cultura por la Universidad Autónoma de Madrid, laurarampal@gmail.com determinantes para generar rechazo nacional e internacional contra la Junta Militar. En este artículo, por un lado, se presenta de manera general la evolución histórica de la fotografía documental en Chile durante esta etapa, y, por el otro lado, se hace una reflexión a modo de ensayo sobre las principales características de las propias imágenes que se tomaron y se difundieron en relación a las violaciones a los derechos.

Palabras clave: Fotografía, Dictadura, Chile, Derechos Humanos, Memoria

\begin{abstract}
The social demand that prevails in Chile on the recovery of the memory of the most sensitive events in the country, during the years of the military regime (1973-1990), has resulted in the publication of several books of pictures taken during those years. For this reason, a significant number of documentary photographs are currently available, which illustrate the repressive practices committed by the security forces. Images were decisive to generate national and international rejection against the Junta Militar. This article, on the one hand, presents a general view of the historical evolution of documentary photography in Chile during this period. On the other hand, it develops a reflection on the main characteristics of the images taken and disseminated that were related to violations of rights.
\end{abstract}

Key words: Photography, Dictatorship, Chile, Human Rights, Memory 


\section{Introducción}

Durante los años en los que el régimen militar controló Chile (1973-1990) serealizaron una vasta cantidad de fotografías que guardaban relación con la represión, las violaciones a los derechos humanos y el activismo político. Posiblemente, entre todos los sistemas autoritarios que asolaron América Latina durante el marco de la Guerra Fría, la dictadura de Pinochet sea la más fotografiada y cubierta mediáticamente, tanto a nivel nacional como internacional. Si hacemos una mirada aún más lejana, probablemente, también la sea a escala mundial. Si bien es cierto que no son pocos los reportajes que existen sobre la situación política y social de otras partes del planeta, fundamentalmente son puntuales, o bien no tuvieron el alcance periodístico y cultural como lo tuvo Chile durante los años de plomo. Las razones de esta característica son varias: la larga tradición y profesionalización del medio fotográfico que se venía consolidando desde el siglo XIX', el desarrollo tecnológico de los equipos de fotografía, la experiencia de la fotografía social en el país desde los años cincuenta, y la llegada de no pocos corresponsales extranjeros interesados en el éxito político y social de la Unidad Popular y las transformaciones realizadas por el presidente

\footnotetext{
Desde su llegada en 1843, la fotografía tuvo un creciente desarrollo en el territorio chileno. Comenzando con los viajes de reconocidos daguerrotipistas, pasando por la apertura de establecimientos de retratos, la consolidación de alianzas y agrupaciones de fotógrafos y la aparición de revistas ilustradas, salones y certámenes, poco a poco se fue popularizando y a su vez profesionalizando esta práctica. Como en el resto del mundo, su uso permeó disciplinas tan variadas como el arte, el periodismo, la medicina o la publicidad, e incluso se incorporó en las funciones del estado. Para comienzos de los años setenta, Chile contaba con un escenario fotográfico bien desarrollado en variados campos y por numerosos autores. Precisamente, para 1973 se inauguró la Escuela Foto Arte de Chile, seguida al poco tiempo por la creación de la Licenciatura en Fotografía en la carrera de Artes Visuales de la Universidad de Chile. Véase: Chile a Través De La Fotografía, 1847-2010. Véase: (RODRIGUEZ 2010).
}

Salvador Allende. Igualmente, la producción fotográfica se favoreció de la relativa facilidad y seguridad con la que se podía viajar por el país, así como por la valentía de los propios fotógrafos a la hora de retratar lo que estaba sucediendo. En el caso de que la violencia en Chile hubiera adquirido los altos niveles de otros países latinoamericanos como Perú, Argentina, Guatemala o El Salvador, la cobertura y el alcance del fotoperiodismo habría sido más limitado.

Las fotografías sacadas durante la dictadura van adquiriendo, con el pasar de los años, un valor histórico incalculable. Prueba de ello es la significativa cantidad de trabajos que se vienen publicando desde hace aproximadamente diez años, no únicamente del periodo autoritario, sino también de etapas anteriores ${ }^{2}$. También se evidencia en las múltiples apropiaciones y resonancias que muchas de estas imágenes han tenido en la producción artística, el cartelismo o la propaganda, incluso en el escenario internacional. Sin embargo, el valor y el papel de las fotografías han cambiado significativamente con el tiempo. Si bien en un principio se trató de denunciar y documentar el escenario que se vivía, a día de hoy, las mismas imágenes se insertan en marcos de reflexión y memoria.

En lo que se refiere a las fotos de la época de la dictadura, cabe señalar que no siempre se conoce su autor, especialmente de aquellas de los años setenta, por el peligro que representaba mostrar el rostro y el nombre públicamente en un acto que las fuerzas de seguridad consideraban subversivo. Por esta razón, numerosas de las

\footnotetext{
Varias editoriales chilenas se han especializado en la publicación de libros de fotografía histórica, como lo son Ocho Libros, LOM, RIL, Pehuén, Metales Pesados e incluso el propio Museo de la Memoria y los Derechos Humanos, por señalar algunas de ellas.
} 
fotos que se publican hoy día permanecen anónimas, o en muchos casos cuestionada ${ }^{3}$, en fondos de organizaciones o medios de comunicación como La Nación, La Vicaría de la Solidaridad, La Comisión Chilena de Derechos Humanos, entre otros.

La demanda y el éxito de venta de estos trabajos reflejan la necesidad de recuperar la memoria visual de esta etapa, tanto para quienes la vivieron como para quienes no. Pues como bien lo nombra el filósofo Georges Didi-Huberman, "para saber hay que imaginarse" (Didi-Huberman 2004: 17). Las imágenes son una parte fundamental del conocimiento y del entendimiento, en este caso, de lo que fue la dictadura en todas sus dimensiones. En este aspecto, cabe destacar que las generaciones más jóvenes de historiadores y de otras disciplinas interesadas en investigar los años del régimen militar no conocieron o bien no tienen claros recuerdos de la cotidianeidad de Chile anterior a 1990. La misma situación ocurre con los académicos extranjeros. Las imágenes presentan no solo escenas comunes de la vida en Chile, sino también otros aspectos que permiten dimensionar y definir con más claridad los referentes visuales de aquella época, como podrían ser sus costumbres, los sentimientos, las modas, las expresiones, la indumentaria, las armas y los vehículos de las fuerzas de seguridad, así como los edificios, las calles, las avenidas y los parques de la ciudades, algunas de las cuales ya no existen o han sido alteradas como consecuencia de la propia transformación urbana.

Sin embargo, hasta ahora, el propio campo de la historia a penas se ha preocupado de analizar

A modo de ejemplo, véase: Fragmentos / Memorias / Imágenes. $A$ 40 años del golpe (Museo de la Memoria y los Derechos Humanos 2013). y comprender el valor de las fotografías del periodo dictatorial de Chile. La mayoría de los estudios realizados proceden de la historia del arte, la teoría estética o de las ciencias sociales, y no se centran en analizar el valor documental de las fotografías a modo individual ni tampoco de manera comparada. El historiador, por lo general, ha estado utilizando estas imágenes para ilustrar puntualmente algunos de los acontecimientos o procesos históricos que describe en su narración, sin llegar a centrarse detenidamente en sus características visuales, su circulación o su papel en la construcción de imaginarios e identidad nacional. Entre los pocos investigadores que se han preocupado por entender con rigor el significado de la fotografía en dictadura se encuentran principalmente Gonzalo Leiva Quijada (2008), cuyos trabajos se citan en este texto, Ángeles Donoso Macaya (2012), Nelly Richard (2007) y Jaume Peris Blanes (2009), entre otros.

Este artículo es una aproximación a modo de reflexión personal del significado histórico de las imágenes que guardan relación con la dictadura militar, ya fueran tomadas durante esos años o después de la restauración de la democracia. Para lo cual, se hace una breve reconstrucción histórica de la fotografía relacionada al periodo dictatorial. Adicionalmente, se identifican y analizan características de dicha producción fotográfica y su valor tanto documental como político.

\subsection{Elementos y características de la fotografía documental de la dictadura militar}

A diferencia de la mayoría de las dictaduras latinoamericanas, la toma violenta del poder fue fotografiada desde el propio 11 de septiembre de 1973. En dicho escenario fue capturada la 
última imagen conocida del presidente Salvador Allende por su fotógrafo personal, Luis Orlando Lagos Vásquez, también conocido como "Chico Lagos". En ella se aprecia al mandatario haciendo su último recorrido por el Palacio de la Moneda antes de ser bombardeado. Allende es retratado con un casco, una metralleta en la mano y su mirada dirigida al cielo, seguramente en alerta a los cazas de la Fuerza Aérea de Chile $(\mathrm{FACH})$ que sobrevolaban la escena ${ }^{4}$. Esta imagen es un documento sumamente valioso por haber dado a conocer los últimos momentos de vida y, todavía en el poder, de Allende, pero además, porque representa el quiebre que vivió en ese instante el medio fotográfico en Chile. Las dificultades para la difusión y el necesario anonimato del fotógrafo comprometido dan cuenta de la represión y la censura que se aplicaron cuando Pinochet llegó al poder ${ }^{5}$.

A pesar de la dificultad que implicó capturar y publicar imágenes del golpe, las que pudieron ser conocidas generaron una gran conmoción nacional, regional y mundial por su propio valor simbólico. El Palacio de la Moneda, el edificio público más importante del país, referente de la democracia y los valores republicanos, fue bombardeado intensamente mientras el Presidente Allende y sus más cercanos

Imagen disponible en: http://www.worldpressphoto.org/people/ orlando-lagos

Esta fotografía fue conocida a través de la prensa internacional tres semanas después del golpe y el nombre del fotógrafo fue revelado hace tan solo pocos años. En el contrato de venta firmado por el fotógrafo con el diario New York Times se especifica la protección de su identidad. Aun así, la casa de Lagos fue allanada en repetidas ocasiones y nunca pudo recibir la remuneración del periódico correspondiente a la venta de esta imagen y de otras seis del mismo evento. Esta fotografía es, seguramente, uno de los retratos más importantes del siglo $X X$, con una gran resonancia internacional. Fue nombrada foto del año 1973 por la International World Press Photo (Véase, Leiva Quijada 2008: 33). colaboradores resistían en su interior ${ }^{6}$. El lugar resultó completamente destruido y su restauración duró varios años. Cabe añadir que también hay grabaciones de los aviones atacando el recinto gubernamental tomadas a escasa poca distancia, las cuales, junto con el sonido de las bombas, el humo saliendo por las ventanas, las paredes derrumbándose y el ruido de los motores de los aviones, no solo añaden un fuerte dramatismo a ese momento, sino que aportaron a la consolidación de ciertos imaginarios en relación a este momento histórico. Imaginarios en plural, pues no hay que olvidar que las mismas imágenes pueden tener lecturas completamente diversas. Como señala Sontag:

\footnotetext{
"Las fotografías de una atrocidad pueden producir reacciones opuestas. Un llamado a la paz. Un grito de venganza. O simplemente la confundida conciencia, repostada sin pausa de información fotográfica, de que suceden cosas terribles" (Sontag 2010: 128).
}

En este caso, no se trata de lo que muestran formalmente las imágenes, sino de lo que cuentan a quien las ve y/o a quien las presenta.

El bombardeo de La Moneda no fue el único acontecimiento retratado en ese primer ejercicio de las Fuerzas Armadas. También se encuentran las imágenes de los movimientos de tropas y de vehículos pesados por el centro de Santiago, así como de los allanamientos y de las incautaciones de libros, folletos, pancartas, afiches y obras artísticas con contenido político de izquierda o producidos por el gobierno de la Unidad Popular. Posteriormente el material se amontonaba en la calle para proceder de manera inminente a su calcinación, en ocasiones frente a las cámaras de los periodistas, las cuales no ge-

Para entender el valor simbólico de este edificio, véase: Chile. Memorias de La Moneda. La (re) construcción de un símbolo político (Bianchini 2012). 
neraran pudor alguno a los soldados. A ellas se empezaron a sumar fotografías de detenciones, de registros de casas y de vehículos, de cadáveres en el rio Mapocho o en las cunetas de las carreteras, de personas asesinadas con signos de torturas, de prisioneros en centros de detención improvisados sobre la marcha para poder concentrar las altas cifras de arrestos, así como de recintos diplomáticos y de organismos internacionales abarrotados de asilados.

La tragedia y la angustia que las imágenes comenzaron a causar a los simpatizantes de la Unidad Popular que hasta el momento no habían sido detenidos, potenciaron sus ansias de partir al extranjero. En los países occidentales y del resto de América Latina hicieron estallar un movimiento de solidaridad con las víctimas de la dictadura que empezó al reclamar el respeto de los derechos humanos y la reinstauración de la democracia.

A su vez, la mano ejecutora de esta violencia, las Fuerzas Armadas con los cuatro integrantes de la Junta Militar al frente, se identificaba con personas uniformadas, rostros serios y armas. Desde ese instante, las fotografías de los dos sectores adquirieron características opuestas, no únicamente en la vestimenta, en las condiciones físicas o en el propio lugar espacial en las que se representaban, como podía ser un recinto de detención o un basurero, sino también los rostros de desamparo, angustia o sufrimiento de las víctimas, frente a la frialdad y arrogancia que mostraban los represores.

Una característica que generalmente ha pasado por desapercibido por los académicos interesados en el análisis visual de esta etapa es la indumentaria y la composición social de las víctimas y de los victimarios. Con el golpe de Estado, la alta burguesía volvió a ocupar los espacios mediáticos y urbanos a los que estaban acostumbrados, dado que durante la etapa de la presidencia de Salvador Allende aparecían en manifestaciones callejeras protestando contra las reformas económicas que se fueron aprobando. Nuevamente, desde el 11 de septiembre de 1973, fueron retratados en reuniones de salón o disfrutando de espacios de alto confort siguiendo la moda occidental con joyas valiosas y ropa ostentosa. La clase trabajadora y sus necesidades prácticamente desaparecieron de los canales y de los medios oficiales de comunicación.

A su vez, la composición étnica que aparece en las fotografías de los partidarios de Pinochet y los opositores es claramente diferente. La realidad, en cambio, era más compleja, ya que personas con distintas características se cruzaban entre los dos bandos. No obstante, tanto la oficialidad como la prensa de oposición, casualmente coincidían en la imagen que querían dar de su contrario con fines propagandísticos. Si bien la oficialidad no se preocupó, por lo general, de retratar a la clase trabajadora o los sectores más desfavorecidos, cuando ello ocurría, al igual que pasaba por el otro lado, aparecían personas con rasgos indígenas o claramente mestizos, y con un aspecto y una vestimenta descuidada. La única diferencia era el marco, la perspectiva y el rostro elegido a retratar, pues si la oficialidad tenía la intención de condenar a este sector por ser negligente e imprudente, desde el otro grupo, se buscaba lo contrario, generar emociones y sentimientos de empatía y solidaridad por las personas más desfavorecidas del régimen militar.

En lo que se refiere a la clase alta, se daba una situación parecida. La oligarquía generalmente 
se mostraba con aspecto europeo, sin ascendencia indígena, y cuando aparecían algunos rasgos mestizos, siempre se intentaban camuflar a través de distintas pericias. La elegancia, la belleza, el orden y la limpieza con la que se representaba a este sector por parte de la oficialidad tenían la intención de indicar que era el resultado de su sacrificio, de su esfuerzo y de su disciplina. La oposición tenía la idea contraria, se representaba como un grupo que se aprovechaba de su poder para oprimir y explotar a los trabajadores para poder disfrutar de sus privilegios gracias a la alianza acordada con las Fuerzas Armadas.

La imagen del folklore fue un aspecto, asimismo, central en la imagen que se quiso retransmitir de las víctimas y de los victimarios. La oligarquía, los soldados y sus simpatizantes jamás se representaban con elementos visuales que recordaran a la política cultural de la Unidad Popular o a la vestimenta de sus partidarios. Por esta razón, generalmente siguieron estilos y artistas procedentes del extranjero, o chilenos siempre que no guardaran relación alguna con elementos indígenas o populares. El charango, el poncho, el tambor, las flautas quena y zampoña, el gorro andino, los diseños con motivos de los pueblos originarios, e incluso la guitarra española, se asociaron con la precariedad, la disidencia y el desorden, además del socialismo y las ansias de revolución. Cuando estos elementos aparecían en las imágenes de los medios, se veían acompañados de comentarios que hacían llamamientos directos para erradicar estas particularidades estéticas, apelando a las normas fijadas por instituciones como el Ministerio de Educación Pública (Leiva y Errázuriz 2012: 26). De esa manera, las autoridades militares y la oligarquía hacían alusión a estas costumbres mostrando sin amparo sus prejuicios y su desprecio. Los elementos folklóricos indígenas pasaron de ser símbolos de resistencia contra el europeo, a símbolos contra la dictadura militar. La oposición, especialmente la clase trabajadora y los estudiantes, en cambio, hicieron de estos elementos una bandera de identidad contra la represión militar y el modelo económico neoliberal impuesto por hombres de corbata y chaqueta procedentes de la Facultad de Economía de la Pontificia Universidad Católica, conocidos como los Chicago Boys por haber realizado estancias de investigación en la universidad de dicha ciudad bajo la dirección de Milton Friedman.

Esta serie de patrones visuales se consolidaron rápidamente y se repitieron hasta el fin de la dictadura. Si bien es cierto que antes y después de esa etapa los elementos identitarios culturales y políticos tanto de la oligarquía como de la clase trabajadora han estado definidos con las características indicadas, fue durante esos años cuando estuvieron más acentuados y confrontados ${ }^{7}$. El esquema se conformó tanto dentro como fuera de Chile, especialmente en aquellos países donde el movimiento de solidaridad fue importante o se estableció una significante comunidad de exiliados. Además, no se puede pasar por alto que, grosso modo, esta distinción visual en lo que se refiere a los elementos que están enmarcados en las fotografías de uno u otro sector, eran similares para el resto de países de América Latina que estaban sufriendo la misma situación política.

Desde sus inicios, el régimen militar desarrolló una "operación limpieza" donde a partir de distintos entes públicos se buscó impartir determinados esquemas culturales y morales, así como abatir todos ellos que significaran un "riesgo" para el "deber ser nacional". Paradójicamente la cultura era entendida como un arma de doble filo (Leiva y Errázuriz 2012: 26). 
Cuando se miran las imágenes de víctimas de la dictadura, ya fueran de los desaparecidos, de los ejecutados políticos o de las personas que aparecen detenidas $\mathrm{y} / \mathrm{o}$ en las protestas, las características físicas son similares. En su mayoría pertenece a una clase social que no comparte fenotipos ni estilo con la clase dirigente. En cualquier caso, los soldados y bajos oficiales que vigilan o custodian a los prisioneros o patrullan por las calles, aunque suelen pasar casi por desapercibidos, comparten la fisonomía de las víctimas, dado que pertenecen a la misma categoría social.

Habitualmente, fueron las víctimas quienes aparecían enfocadas y bien enmarcadas. Las fuerzas represivas, en cambio, no solían aparecer nítidas ni frente a la cámara. Por lo cual, no se puede individualizar a los militares ni carabineros, a no ser que haya una intencionalidad clara por parte del fotógrafo de conocer al responsable directo de una acción represiva determinada, o de la autoridad máxima de la situación de injusticia, como ocurriría con las fotografías de Pinochet y otros altos mandatarios. Las fuerzas represivas aparecen representadas como una masa o un conjunto de personas que actúan en colectivo, de manera mecánica, sin responder a cuestiones éticas ni morales. En cambio, a la víctima siempre se le intenta dar el mayor protagonismo posible dentro del escenario, y a pesar de que la fotografía es una imagen fija, se espera que su rostro, la expresión de su mirada, su posición y sus características físicas, logren comunicar y transmitir toda la información posible de esa persona, así como emociones que generen un fuerte vínculo afectivo.

En cualquier caso, las víctimas no siempre aparecen representadas en una misma situación, de manera que se pueden distinguir los siguiente tipos de categorías fotográficas: imágenes de cadáveres, de detenidos y torturados durante y después de su reclusión, de manifestantes, de desaparecidos y ejecutados políticos antes de ser apresados, de sus propios familiares ${ }^{8}$ $\mathrm{y}$, en último lugar, de huellas de la violencia vivida por la víctima, como puede ser la ropa encontrada en fosas comunes o de otros elementos simbólicos y/o alusivos, por ejemplo, a la ausencia de los desaparecidos ${ }^{9}$. Todas ellas buscaban despertar la empatía con el público a través del impacto, aunque las emociones fueran de distinta índole.

Las imágenes de cadáveres producen indignación y furia, aunque al no ver los rostros, los sentimientos de empatía son menores. En cambio, las fotos de individuos que aparecen vivos mirando a la cámara, causan una mayor conexión. La mirada a la cámara hace partícipe al espectador, lo involucra y lo incluye en el escenario retratado. Se rompe la peligrosa frialdad y la distancia con la que puede cargarse el marco fotográfico (Butler 2010: 110). Dentro de esta categoría están, por un lado, quienes sufren o han sufrido violencia en el momento de tomarse la fotografía, tales como manifestantes que son reprimidos $\mathrm{y} / \mathrm{o}$ quienes ya están detenidos $y$, por el otro, quienes no pudieron ser retratados durante su reclusión y, por ende, únicamente se dispone de fotografías anteriores o posteriores a esa situación. En este segundo exiliado político, grupo del que hay un alto número de fotografías mientras residían en distintos países del mundo. No obstante, en este trabajo se centra exclusivamente en las fotografías que se tomaron dentro de las fronteras nacionales. Para conocer un ejemplo de fotografías del exilio, véase: Suecia por Chile. Una historia visual del exilio y la solidaridad 1970-1990 (Camacho Padilla 2009).

9 Un interesante trabajo fotográfico donde se apela a la huella como imagen del desaparecido es La Caravana de la Muerte: Las víctimas de Pinochet (Sánchez 2001). 
caso, la representación de los hechos violentos termina por traspasar los límites de su propia visualidad. La violencia se nos presenta desde su propia ausencia, desde imágenes que la anteceden, normalmente en diálogo con la palabra que la enuncia.

Es difícil establecer cuál de los dos modelos tienen mayor efecto en el espectador, si el retratado que ha sido reprimido antes de tomarse la foto o después. La diferencia entre la primera y la segunda es importante. En la primera, la atención se focaliza en el drama que ha vivido esa persona, que queda reflejada en su propia mirada y gestos de la cara. La tristeza y el dolor que transmiten hacen pensar al espectador en el sufrimiento y el tipo vejaciones que sufrió esa persona. La reflexión no suele ir más allá de ese momento.

Por el contrario, la fotografía del detenidodesaparecido o del ejecutado político transmite unos sentimientos y unas impresiones claramente distintas. Cuando la fotografía presenta una escena cotidiana de la vida privada del asesinado, ya sea acompañado de familiares y/o amigos, o incluso en solitario, pero disfrutando de un momento determinado, la reflexión del espectador se desarrolla en las consecuencias de su asesinato para esa persona y sus allegados, en cómo su felicidad y su vida fueron interrumpidas por un acto injusto y violento (Richard 2007: 117). Si en el primer tipo de fotografías es la tortura y/o la detención el punto central en el que se centra la atención, en la segunda es la alegría de vivir abortada de la persona asesinada. Ello es favorecido a su vez, porque las fotografías seleccionadas por los familiares del ejecutado, por lo general, lo muestran en un buen momento, el cual fortalece y potencia su carácter humano.
Además, el testimonio de personas cercanas que acompañaban las imágenes, fue lo que terminó por cargarlas de con la violencia que no es retratada directamente. De este modo, se fija una narrativa visual mucho más compleja, pues incita el espectador a posicionarse en el lugar de la víctima.

Sin embargo, la mayoría de las fotografías de los detenidos-desaparecidos y de los ejecutados políticos fueron sacadas de sus pasaportes o documentos de identidad ${ }^{10}$. Su rostro es neutral y aparece bien enmarcado. Este tipo de imágenes apenas entrega información colateral sobre el detenido-desaparecido, pero resulta vital para entender que se trató de una persona común y corriente $y$, sobre todo, que verdaderamente existió. En cualquiera de los dos casos, se sacó provecho de una de las características más significativas de la fotografía. Su posibilidad de señalar, evidenciar, demostrar que 'algo ha sido', pues en palabras de Roland Barthes:

\begin{abstract}
"La fotografía es literalmente la emancipación del referente. De un cuerpo real, que se encontraba allí, han salido unas radiaciones que vienen a impresionarme a mí, que me encuentro aquí; importa poco el tiempo que dura la transmisión; la foto del ser desaparecido viene a impresionarme al igual que los rayos diferidos de una estrella" (Barthes 1990:142).
\end{abstract}

Poner rostro a los desaparecidos fue sumamente necesario para desmentir la información oficial de que estas personas no existían o bien habían huido del país por razones personales.

\footnotetext{
Cabe resaltar el importante papel que ha tenido la fotografía de los documentos de identificación en la consolidación de la identidad de los ciudadanos, entendida desde la dimensión física, es decir, su propia existencia, sobrepasando las particularidades humanas, como serían los intereses políticos, las creencias religiosas y la orientación sexual. En el caso de Chile, desde 1903 se creó el Gabinete de Identificación y en 1924 se hizo obligatoria la tarjeta de identidad con foto (Rodríguez 2010: 32).
} 
La propia estructura de la fotografía del documento de identidad, donde se presenta un formato normalizado (frontal, de fondo blanco o azul) funcionó como herramienta capaz de destacar la parte más humana de los desaparecidos. En este caso, la desubjetivización de las personas apostaba por ser una herramienta que paradójicamente humanizaba su presencia y, a su vez, su ausencia. Es decir, señalaba que se trataba de personas, de chilenos, dejando de lado sus intereses políticos, su género o su religión ${ }^{11}$.

La última categoría de víctimas son los familiares de los detenidos-desaparecidos y ejecutados políticos, muchos de los cuales también sufrieron arrestos o incluso torturas. Sin embargo, su labor se ha centrado en reclamar justicia por los crímenes de su gente y reivindicar su memoria. En todos sus rostros se percibe el dolor, la tristeza, la angustia y la desesperación. Con el paso del tiempo se puede distinguir como estos sentimientos han ido configurando sus caras. Si en un primer momento no estaban tan claramente definidas, su lucha contra la impunidad y la indiferencia ha marcado su físico para siempre. Normalmente son retratados en encuentros con autoridades políticas, en ceremonias, en reuniones o en manifestaciones, quienes a su vez, suelen portar fotografías de sus familiares represaliados, ya sean colgadas del cuello o alzadas en pancartas. De este modo, mientras el físico del detenidodesaparecido o del ejecutado político aparece igual con el pasar de los años, estático en el tiempo, el pariente que la porta consigo sufre el cambio físico propio de la naturaleza humana, donde ahora la madre pareciera que sería la

Véase: Fotografía, Historia y Memoria. Presencia de una ausencia: La fotografía de los detenidos desaparecidos en cuatro momentos (Orrego 2013). abuela o bisabuela, o el hermano o incluso el hijo, un pariente mayor del retratado.

Este fenómeno hace que la situación se vuelva confusa para quien no tenga un conocimiento claro de los crímenes de lesa humanidad y del marco temporal. Desde estas fotografías, familiares y amigos de los represaliados terminan por materializar su ausencia, pero también a partir de su propia corporalidad. Se evoca la ausencia no desde la mímesis, sino desde los afectos que genera la acción de los familiares de las víctimas al recorrer las calles cargados de los rostros de sus seres queridos. Un gesto casi performático, que además ha sido capturado en nuevas fotografías.

\section{Denuncia y militancia a través de la fotografía}

La fotografía social o de compromiso tuvo su punto de partida a comienzos de los años cincuenta en Chile. Si en un primer momento no fueron numerosos los fotógrafos que retrataron la realidad y la cotidianeidad del país, su profesionalidad y su buen ojo, lograron que fueran mundialmente conocidos. Entre ellos se destacaron Antonio Quintana ${ }^{12}$, también militante del Partido Comunista, Luis Ladrón de Guevara, funcionario de la Corporación para el Fomento (CORFO), Marcelo Montealegre ${ }^{13}$ y Sergio Larraín ${ }^{14}$, ambos miembros de importantes familias ilustradas del país. De los

\footnotetext{
Uno de los únicos trabajos que reúne su obra ha sido publicado con el título: Antonio Quintana 1904-1972 (Denise Fresard Moreno 2006).

13 Véase el libro No me olvido. Chile 1954-1968 (Montealegre 2011)

14 Dos excelentes publicaciones sobre su biografía y su obra son: Sergio Larraín. Biografía / estética / fotografía (Leiva Quijada 2012) y Sergio Larrain (Agnès Sire 2013)
} 
cuatro, quien obtuvo más prestigio internacional fue Sergio Larraín gracias a que en 1961 entró en la agencia Magnum con pleno derecho. Estas cuatro personas compartían una misma preocupación por los temas sociales, las necesidades de los sectores desfavorecidos, los grupos marginales y sus condiciones de vida. Su fotografía fue varias veces criticada por la alta burguesía chilena bajo la acusación de difundir una percepción negativa de la patria, puesto que, a su entender, la fotografía únicamente debía estar al servicio de la promoción del país a través de la difusión de su belleza y de los logros del gobierno. Los indígenas, la vida en las poblaciones más pobres y los sectores rurales, a su entender, eran aspectos que debían ser ignorados por las cámaras.

Las imágenes de Quintana, Guevara, Montealegre y Larraín fueron publicadas por distintos diarios chilenos como La Nación, La Voz, Ercilla, Vea y Desfile, y expuestas en varios países, siendo de gran influencia en la imagen de Chile que empezó a diseñar la Unidad Popular tras la victoria electoral de 1970. Para lo cual, en 1971 fue fundada la editora nacional Quimantú, cuya finalidad fue centralizar las publicaciones del nuevo gobierno. A partir de ese año, las fotografías de la clase trabajadora empezaron a ocupar un lugar protagónico en las campañas mediáticas de la Unidad Popular.

De sumo interés son las fotografías de la gira de Salvador Allende tomadas por Luis Poirot ${ }^{15}$. También Orlando Lagos, el fotógrafo oficial de La Moneda, realizó un trabajo importante. Además, tanto durante el gobierno de Eduardo

El Museo de la Memoria y los Derechos Humanos publicó hace unos años un excelente trabajo de este fotógrafo: La sopa derramada 1969-1973 (Poirot 2013). Véase también: Identidad fortuita (Poirot 2011).
Frei Montalva (1964-1970) como de Salvador Allende, Juan Domingo Marinello ${ }^{16}$ y Patricio Guzmán Campos ${ }^{17}$ también se preocuparon por registrar la vida social y política del país. A todos ellos se suman un significativo número de fotógrafos extranjeros que se desplazaron a Chile para poder captar con sus cámaras las transformaciones que estaban en marcha, entre quienes estaban el francés Raymond Depardon ${ }^{18}$, el sueco Karl Jagare ${ }^{19}$ y el portugués Armindo Cardoso.

Con el golpe militar, el proyecto quedó desmantelado y la imagen que se empezó a transmitir desde la oficialidad fue profundamente distinta y crítica contra la experiencia de Salvador Allende (Leiva y Errázuriz 2012), tal como demuestran las publicaciones El libro blanco del cambio de gobierno en Chile (Secretaría General del Gobierno 1973), y Chile. Ayer hoy (Editora Nacional Gabriela Mistral 1975). Ambos eran parte de los llamados 'Documentos del miedo', que pretendían "diseñar un plan de penetración psicológico masivo para destruir la doctrina marxista" (Gamarnik 2012: 2). La Unidad Popular se presentaba como sinónimo de caos y violencia, mientras que el régimen militar significaba estabilidad y orden. A su vez, la narrativa visual aplicada en estas publicaciones también abarcaba las estrategias gráficas y de diagramación propias de la propaganda política con la finalidad de cargar positiva o negativamente las imágenes. En la publicación Chile. Ayer y hoy, por ejemplo, las fotografías

\footnotetext{
Véase el libro Punto Ciego (Juan Domingo Marinello 2015).

17 Una interesante recopilación de imágenes se encuentra en: Chile en la retina. Fotografías 1957-1973 (Patricio Guzmán Campos 2010).

18 Véase: Chile 1971 (Raymond Depardon 2013).

19 Ver: Érase una vez 1971-1972 (Karl Jagare 2009)
} 
del ayer se presentaban con un marco negro y las del hoy con uno blanco ${ }^{20}$.

No obstante, la violencia con la que se perpetró el golpe de Estado y que caracterizó a la dictadura durante toda su etapa no logró hacer desaparecer por completo las temáticas sociales en la fotografía. Indirectamente más bien las fomentó ya que la solidaridad y la empatía que generaban las víctimas tuvieron como resultado una preocupación mayor por los sectores desfavorecidos y reprimidos. En esta dirección, se debe diferenciar dos etapas en la producción fotográfica en dictadura en función a sus distintas características. La primera se enmarca desde septiembre de 1973 hasta 1980, y la segunda, desde 1981 hasta 1990.

Durante la primera fase, la represión masiva ejercida por los aparatos de seguridad de la dictadura impidió cualquier tipo de actividad opositora. La Unión de Reporteros Gráficos estaba claramente limitada por Dirección Nacional de Comunicación Social (DINACOS), el organismo responsable de controlar la difusión de imágenes. Por lo tanto, en estos primeros años, todos los diarios que circulaba en el país tenían un carácter oficial, a excepción de las publicaciones que pertenecían a los organismos de derechos humanos y a la prensa clandestina de los partidos políticos de oposición. Además, los fotógrafos chilenos sabían del peligro que suponía criticar y denunciar al régimen, de modo que eran pocos los que tenían la valentía de hacerlo abiertamente. Por lo general, las primeras imágenes que circularon por los canales de la oposición mostraban reuniones

20 Estas mismas estrategias fueron utilizadas en otros países de América Latina que vivieron dictaduras, como lo fueron Argentina y Uruguay. Véase el artículo: Fotografía y dictaduras: estrategias comparadas entre Chile, Uruguay y Argentina (Gamarnik 2012). y manifestaciones de las agrupaciones de familiares de detenidos desaparecidos ${ }^{21}$ y de ejecutados políticos, cuyos integrantes empezaban a portar los retratos de sus familiares asesinados.

En un primer momento, fotógrafos chilenos y extranjeros recogieron la brutalidad que acompañó al golpe militar. Las imágenes de los hermanos chilenos Christian y Marcelo Montecinos $^{22}$, los argentinos Horacio Villalobos y Domingo Politi, el holandés Koen Wessing ${ }^{23}$, el estadounidense David Burnett o el holandés Chas Gerretsen, han sido internacionalmente conocidas hasta el día de hoy. Junto a ellos, estaban corresponsales de los principales diarios del mundo, y varias de las fotografías recibieron importantes premios, como la mejor foto periodística de World Press Photo mencionada anteriormente, y la medalla Robert Capa.

No obstante, la dureza de la represión clandestina, el cierre de los medios favorables a la Unidad Popular y la detención masiva de los periodistas afines tuvieron como consecuencia una disminución de la labor periodística de oposición. Una vez que los militares depuraron

21 El mejor trabajo de imágenes de la agrupación es: 20 años de historia de la Agrupación de Familiares de Detenidos Desaparecidos de Chile. Un camino de imágenes que se revelan y se rebelan contra una historia no contada (Díaz Caro, Sierra Henríquez y Adolfo Becerra 1997). Un profundo análisis de las fotografías utilizadas por la agrupación se titula Fotografía, Historia y Memoria. Presencia de una ausencia: La fotografía de los detenidos desaparecidos en cuatro momentos (Orrego Standen 2013)

22 Existen varias publicaciones de los hermanos Montecinos. Entre ellas, se destacan Irredimible. Diario/1973 (Montecino 2011), Las calles de las penas (Montecino 2014) y Marcelo Montecino 50 años (Montecino 2013).

23 Las mejores imágenes de su trabajo en América Latina se encuentran en: Fotografнa. El arte de visibilizar la pregunta (Koen Wessing 2011) 
las instituciones públicas y los espacios dominados por los partidarios de la izquierda, la visibilidad de la represión se hizo mucho menor. A su vez, el terror generado en la población por la crueldad con la que se tomó el poder paralizó casi por completo los intentos de registrar visualmente lo que estaba pasando. Cabe recordar que entre 1973 y 1981 fueron asesinados los fotógrafos Christian Montecino, Hugo González Araya, Ricardo Troncoso León, René Vallejos Parra, Teobaldo Tello Garrido, Francisco Rosas Contador, Manuel Bobadilla Bobadilla, Hernán Pérez Álvarez y Leandro Arratía Reyes (Leiva Quijada 2008: 41), lo cual causó mucho temor en el gremio.

Los únicos que continuaron fotografiando el país fueron corresponsales extranjeros, aunque con gran cuidado y sutileza, dado que podían ser arrestados, torturados o expulsados del país, como ocurrió a Bobbi Sourander, periodista del diario Dagens Nyheter de Estocolmo. Sourander permaneció detenido varios días en el Estadio Nacional y sufrió todo tipo de vejaciones. A pesar de esta experiencia, diarios extranjeros continuaron publicando fotografías de lo que acontecía en Chile, aunque a comienzos de 1974 se suavizó el nivel de dramatismo y sensacionalismo que tuvieron en los días inmediatos al bombardeo del Palacio de la Moneda.

Como consecuencia de esta realidad no fue hasta el inicio de la década de los años ochenta cuando la fotografía documental relacionada con los derechos humanos y el activismo, empezó a recuperar importancia. Un primer punto de partida fue el descubrimiento de 15 restos de cuerpos humanos en los hornos de Lonquén en noviembre de 1978. Antes de la llegada de los Carabineros, miembros de la
Vicaría de la Solidaridad verificaron los hechos y llevaron consigo al fotógrafo Luis Navarro para que tomara imágenes del lugar. Se trató de la primera aparición de cadáveres de personas que habían sido detenidas tras el golpe y se encontraban desaparecidas. Lonquén fue el primer espacio de memoria que se generó y fotografió desde el golpe militar, apareciendo en los medios de comunicación, incluso oficiales, razón por la que el dueño del fundo en el que se descubrieron los cuerpos, en complicidad con la Fuerzas Armadas, decidió dinamitar el lugar poco después.

La carencia de fotografías significativas y representativas de las prácticas represivas aplicadas desde mediados de 1974 hasta 1978 empezaba de ese modo a solventarse. De manera simultánea fueron apareciendo nuevos fotógrafos jóvenes y comprometidos que estaban interesados en mostrar a la sociedad y al mundo la situación política y social que se vivía en Chile. Se trató de profesionales que habían vivido a muy temprana edad el golpe de Estado y sabían del riesgo que tenía esta actividad en el contexto que se vivía. Sin embargo, se fue despertando en ellos una cierta pulsión urgente por registrar y dar a conocer lo que se vivía en el país ${ }^{24}$. Eran testigos que necesitaban generar un testimonio visual. Sin embargo, la propia

Esta pulsión se hace evidente en los testimonios fotográficos a partir de la repetición de imágenes. Un ejemplo claro se encuentra en series fotográficas capturadas con una escasa diferencia temporal, o incluso donde aparecen otros fotoperiodistas capturando la misma escena. Esto último sucede, por ejemplo, entre las imágenes de fotoperiodistas como Marco Ugarte y Juan Carlos Cáceres. No importa que el otro ya esté o haya registrado lo que se le presenta ante sus ojos, no importa que la última toma ya haya capturado la escena, hay una necesidad por aprehender la violencia en su suceder. Pareciera que están en búsqueda de un instante, un encuadre, o un ángulo que pudiera hacer comprensible lo que se les presenta ante los ojos. Sin embargo, hay algo que se les escapa que los obliga a continuar presionando el obturador. Véase: La desubjetivización del testimonio (Ramírez 2015, 52). 
naturaleza testimonial carga en sí su propia contingencia. El testimonio inevitablemente se ve amenazado cuando hace referencia a la violencia. La represión, la tortura, el control mediático, así como la propia dificultad de mirar escenas escabrosas, amenazó la posibilidad práctica que las imágenes alcanzaran su materialidad. Paradójicamente, esa amenaza solo despertaba con mayor fuerza la necesidad de visibilizar, pues entendían la fotografía como un arma capaz de protegerlos de la amenaza del desconocimiento, de la indiferencia o de la incomprensión. En palabras del fotógrafo de Oscar Navarro:

"Cuando fue creciendo mi capacidad para comprender lo que ocurría con mí país, más que un canal propio, vi la posibilidad de decir lo que estaba viviendo un 'pueblo completo'. Así llegué al reportaje gráfico y cuando comenzaron las movilizaciones vi que con la fotografía tenía un arma poderosa" (Leiva Quijada 2008: 78).

Las imágenes operaban como un dispositivo capaz de hacer real lo que para muchos resultaba inimaginable.

"Las fotografías son un medio que dota de 'realidad' (o de 'mayor realidad') a asuntos que los privilegiados o los meramente indemnes acaso prefieren ignorar" (Sontag 2010: 68).

A pesar de los riesgos, esta actitud tan decisiva les empujó a seguir adelante con sus principios, buscando dar a conocer, desde la visualidad, realidades que mediante el solo testimonio escrito o verbal se le escapaban a la imaginación.

El peligro que suponía actuar por libre en el campo del periodismo durante la dictadura, por un lado, y la necesidad de difundir nacional e internacionalmente su obra, a la vez que protegerla, por otro lado, llevó a los fotógrafos que no formaban parte de la Unión de Reporteros
Gráficos a agruparse en lo que se llamó Asociación de Fotógrafos Independientes (AFI), la cual creó su propia revista bajo el título de Punto de Vista, además de organizar numerosas exposiciones. Concretamente, fueron dos hechos determinantes los que empujaron a los fotógrafos a tomar esta decisión. El primero fue la censura de una fotografía de Paz Errázuriz de un desnudo masculino en el Museo de Bellas Artes, y, en segundo lugar, la detención de Luis Navarro en marzo de 1981 (Leiva Quijada 2008: 53), quien también fue sometido a torturas. La aparición de una prensa crítica con el régimen militar, tal como lo fueron las revistas y diarios Análisis, Mensaje, Apsi, Cauce y Fortín Mapocho y Época, entre otros, permitió y favoreció la difusión del trabajo de este colectivo.

De esta manera, el vacío de imágenes de la represión que se había generado en la segunda mitad de la década de los años setenta, quedó compensado con una explosión de fotografías que hacían inundar los archivos de la prensa hasta la restauración de la democracia. La AFI llegó a reunir hasta 300 reporteros gráficos poco antes del fin de la dictadura. Entre los nombres más importantes se encontraron Jorge lanisewsky, Luis Navarro, José Moreno, Inés Paulino, Paz Errázuriz, Juan Domingo Marinello, Helen Hughes, Ricardo Astorga, Leonora Vicuña, Álvaro Hoppe, Alejandro Hoppe, Claudio Pérez, Kena Lorenzini, Óscar Navarro, Héctor López, Luis Weinstein, Marco Ugarte, Marcelo Montecino, Luis Poirot, Paulo Slachevsky y Óscar Wittke. Con estos nombres, y los que no son aquí mencionados, se confirma un fenómeno nuevo en relación a las décadas anteriores, el cual se trata de la llegada de un número importante de mujeres a la profesión. A partir de ahora se hace común encontrar a fotógrafas recorriendo las calles 
de las distintas ciudades del país para buscar imágenes que generen reacciones críticas contra la dictadura, las cuales eran guiadas por una sensibilidad espacial ${ }^{25}$. En cualquier caso, no toda la producción fotográfica de la AFI tuvo un carácter documental, aunque siempre fue crítico $^{26}$. Algunos de los fotógrafos participantes desarrollaron un cuerpo de trabajo cuyo lenguaje se acerca más a lógicas de la producción artística.

Los jóvenes fotógrafos nuevamente realizaron reportajes de la cotidianeidad del país, de la clase trabajadora, de los sectores desfavorecidos y marginados, como lo eran los vagabundos, las personas con limitaciones físicas o psíquicas, y minorías sexuales. A estos temas, se sumaron a partir de 1983, las manifestaciones en rechazo a la dictadura que eran reprimidas a balazos, golpes de porra, bombas lacrimógenas y chorros de agua ${ }^{27}$. En cualquier caso, las imágenes que se intentaban captar, siempre se regían por los mismos patrones, que fueron presentar a las víctimas su dolor y desesperación, bien enmarcadas en el cuadro de la foto, mientras que las fuerzas represivas ejercían la violencia con expresiones de agresividad. Se buscaban instantáneas que condenaran las acciones de los Carabineros frente a los manifestantes con el fin de lograr un mayor impacto mediático a

Para el caso de Hughes, Lorenzini y Vicuña, véase: Visible / Invisible. Tres fotógrafas durante la dictadura militar en Chile (Rojas, González y Fonseca 2012).

26 Luis Weinstein, a propósito de la publicación Punto de Vista, señalaba que la producción fotográfica que propiciaba la AFI debía "tener en cuenta que el fotografiar las protestas no significa necesariamente hacer una 'fotografía de protesta'” (Leiva Quijada 2008: 89)

27 Una pequeña muestra de estos registros de la brutalidad del régimen en estos años aparece en la siguiente obra: Chile 19731990. La dictadura de Pinochet (Hoppe, López, Montecino, y Pérez, C. 2013). través de agitar la moral de los espectadores gracias a su tremendo potencial político (Donoso Macaya 2012: 410).

La realidad política dificultaba enormemente la toma de imágenes de esta naturaleza, además de las amenazas constantes a la que estaban sometidos. Las detenciones de los fotógrafos fue una práctica común por parte de Carabineros, así como la destrucción de los carretes e incluso de los equipos fotográficos. Además, la falta de medios y de recursos afectó profundamente la capacidad de registrar de los fotógrafos, dado que debían cuidar y saber administrar sus carretes de fotos con cuidado. En numerosas ocasiones, los compañeros de medios de comunicación extranjeros les entregaron carretes para que pudiera seguir trabajando ${ }^{28}$. Un momento verdaderamente trágico para la asociación ocurrió el 19 de agosto de 1986 cuando Rodrigo Rojas ${ }^{29}$, uno de sus integrantes, fue detenido y quemado vivo, causando un gran dolor entre sus compañeros y un impacto mediático a nivel internacional.

Las fotografías de la AFI también empezaron a circular internacionalmente a través de publicaciones y de exposiciones que se organizaban en Europa y Estados Unidos. Varias de las imágenes también fueron comparadas por medios de comunicación extranjeros y comités de solidaridad para apoyar la labor del colectivo. La vinculación de los fotógrafos de la AFI con las organizaciones de derechos humanos y los partidos políticos de oposición fue duramente criticada por el régimen $y$

\footnotetext{
28 Véase el siguiente documental donde se da testimonio de esta situación dentro de la AFI: La ciudad de los fotógrafos (Sebastián Moreno 2006).

29 Hace pocos años se publicó el siguiente libro en su homenaje: Un exilio sin retorno (Rojas de Negri 2013).
} 
simpatizantes. La fotógrafa de Magnum Susan Meiselas, de fama mundial, atraída por conocer de cerca la experiencia de la AFI, decidió viajar a Chile con el fin de tratar con sus miembros y ver de cerca la realidad en la que trabajaban. Fruto de su viaje fue la exposición "Chile desde adentro" inaugurada en 1989 en Nueva York con el trabajo de 16 fotógrafos de la AFI, y del que se publicó un catálogo del que salieron varias ediciones $^{30}$.

A pesar de la oleada masiva de imágenes que fueron apareciendo con la creación de la AFI, las fotografías de la década anterior, especialmente aquellas tomadas durante el 11 de septiembre de 1973 y los días posteriores, conservaron un rol central gracias a la dureza y el mensaje que trasmitían, como lo era el bombardeo del Palacio de la Moneda, las detenciones y los cuerpos abandonados en la vía pública. No obstante, estas imágenes no circularon tan abiertamente en Chile como en el extranjero a causa de la censura y los riesgos que suponían su difusión (Peris Blanes 2009: 90). En este sentido, la fotografía obtuvo un rol fundamental en el exterior, dado que los exiliados y aquellos que estaban interesados en seguir el desarrollo de Chile, se interesaban en poder visualizar los acontecimientos.

En el exterior también se encontraban artistas plásticos, tanto chilenos como de otras nacionalidades, que terminaron por incluir las imágenes publicadas internacionalmene en su propia obra. Tal es el caso de Gracia Barrios y José Balmes, o de Roser Bru, Guillermo Deisler, Carlos Altamirano, Eugenio Dittborn, y Alfredo Jaar, entre tantos otros. Su trabajo en el marco del exilio se valió en repetidas

Chile from within (Meiselas 1990) ocasiones del material fotográfico que circuló internacionalmente en relación a la dictadura. Su lenguaje plástico incorporó y/o se apropió de documentos, fotografías y recortes de prensa, que en muchos casos se reutilizaron en el collage. Si bien sus reflexiones plásticas estuvieron condicionadas a su propia experiencia en el exilio, también se presentaron como una resonancia crítica del imaginario visual sobre la dictadura que la fotografía forjó más allá de las fronteras chilenas. Son trabajos que generan una doble distancia con los acontecimientos, pero simultáneamente se trata de una estrategia que termina propiciando una nueva mirada más sobre los estas duras experiencias históricas ${ }^{31}$.

\section{Conclusiones}

A partir de la década de los años cincuenta, la fotografía documental en Chile gozó de un componente ético importante. Hasta el golpe de Estado, el objetivo central fue presentar a los sectores marginados e ignorados de la sociedad, pero tras la llegada de Augusto Pinochet al poder, se sumaron las imágenes vinculadas a las sistemáticas violaciones a los derechos humanos, como fue el bombardeo del Palacio de La Moneda, la quema de libros, las detenciones de personas, y la represión de las manifestaciones, entre otros temas. Además, se difundieron fotografías personales de detenidosdesaparecidos o de ejecutados políticos en la búsqueda de justicia y apoyo social, tanto a nivel nacional como internacional.

Entendemos la mirada bajo los términos del filósofo DidiHuberman: "mirar no es simplemente ver, ni tampoco observar con mayor o menos 'competencia': una mirada supone la implicación, el ser-afectado que se reconoce, en esa misma implicación, como sujeto (Didi-Huberman 2014: 41). 
Con el paso del tiempo, una transformación importante de estas imágenes en relación con el pasado se encuentra en el hecho de que ahora se convierten documentos históricos de episodios determinados de la vida cotidiana en Chile durante los años de la dictadura militar. A diferencia de lo que ocurrió en esos años, en el presente ya no se cuestiona la veracidad de esas fotografías. La mayoría de estas fotografías se han convertido en parte de la memoria colectiva del golpe de Estado y la represión que la acompañó de manera inmediata hasta 1990. Sin embargo, en el momento que se captaron esas imágenes, el objetivo fue denunciar y presentar públicamente los sucesos que se vivían en Chile, aunque no siempre fueron aceptadas. La conocida actitud decisiva y crítica de los propios fotógrafos fue utilizada por la dictadura para poner en duda la veracidad de su obra ${ }^{32}$.

Las fotografías tomadas en los días inmediatos al golpe de Estado o por los integrantes de la AFI constituyen hoy día un pilar visual central de la historia reciente del país. Al presentarse o al hablar del 11 de septiembre o de las protestas de los años ochenta, así como de la identidad de los detenidos-desaparecidos, las imágenes que se vienen a la memoria son aquellas que circularon mayoritariamente por los medios de comunicación y las propias calles de las ciudades del país. Además, estos registros, desde entonces hasta la actualidad, se han reproducido innumerables veces por artistas plásticos. Valiéndose de la distancia que otorga el apropiacionismo, buscaron generar una mirada crítica y condenatoria de la dictadura militar.

Véase: De la prueba documental a la evocación subjetiva. Usos de la fotografía en las publicaciones sobre la represión chilena (Peris Blanes 2009).
La comparación de las fotografías de los años setenta y ochenta también presentan diferencias interesantes. De 1973 se encuentran imágenes del bombardeo del Palacio de la Moneda, de quema de folletos y libros, de detenciones de personas en las calles, las cuales no ofrecen resistencia alguna, de detenidos en recintos de detención, o de sus familiares esperando con angustia su liberación. Los rostros son de sorpresa, tristeza, resignación y dolor. Las fotografías de los años ochenta, en cambio, si bien presentan algunas características comunes como resulta ser el espacio urbano, mayoritariamente en Santiago, en el que transcurren los hechos, vemos, asimismo, diferencias que no son menores. Ahora hay una actitud firme de condena a la dictadura a través de protestas y enfrentamientos directos con las fuerzas de seguridad. Las personas que son detenidas ofrecen resistencia, los fotógrafos no permanecen más en el anonimato, y los rostros son de indignación, lucha, furia, pero también de esperanza. Las fotografías ilustran dos psicologías claramente distintas del pueblo opositor a la dictadura. Una primera etapa donde predomina la sumisión, y una segunda donde se destaca la valentía y la acción.

El carácter testimonial que tomó la fotografía en este periodo, no sólo se entiende por lo que se visualizaba, sino también por su propia materialidad y circulación. La fotografía entendida como imagen, pero también como objeto, fue particularmente representativas de la situación que vivía el país. Tanto las imágenes que tuvieron lugar, como esas otras censuradas, desaparecidas o las que simplemente no pudieron llegar a una fisicidad por la propia represión, conforman un corpus que constituyen hoy el o los imaginarios de la dictadura. 
La recapitulación de trabajos fotográficos y la revelación de autores que en su momento tuvieron que proteger su identidad, como pueden ser el caso de "Chico Lagos" o Michel Boneffoy, son una muestra de la transformación que ha vivido el material fotográfico de la dictadura con el tiempo. Las imágenes ya no se presentan solamente como la representación de un evento particular, en el sentido mimético, sino que evocan temas más complejos y construyen retóricas en relación a la violencia, la tortura, el dolor $o$ el sufrimiento. La imagen comienza a ser leída ya no desde la urgencia por denunciar los acontecimientos que se vivían, sino como herramientas de reflexión, memoria y reparación social.

\section{Bibliografía}

Barthes, R. 1990. La Cámara Lúcida: Notas sobre fotografía. Barcelona: Editorial Paidós.

Bianchini, M. C. 2012. Chile. Memorias de La Moneda. La (re) construcción de un símbolo político. Madrid: UAM Ediciones.

Butler, J. 2010. Marcos de Guerra: Las vidas Iloradas. Madrid: Paidós.

Camacho Padilla, F. 2009. Suecia por Chile. Una historia visual del exilio y la solidaridad 1970-1990. Santiago: LOM Ediciones. Mistral.

Chile. Ayer hoy. 1975. Santiago: Editora Nacional Gabriela

Depardon, R. 2013. Chile 1971. Santiago: LOM Ediciones.

Díaz Caro, V., Sierra Henríquez. S. y Adolfo Becerra. G. 1997. 20 años de historia de la Agrupación de Familiares de Detenidos Desaparecidos de Chile. Un camino de imágenes que se revelan y se rebelan contra una historia no contada. Santiago: Corporación Agrupación de Familiares de Detenidos Desaparecidos de Chile.

Didi-Huberman, G. 2004. Imágenes pese a todo: Memoria visual del Holocausto. Barcelona: Paidós.

Didi-Huberman. G. 2014. "La emoción no dice 'yo'. Diez fragmentos sobre la libertad estética” en Jaar, A. La política de las imágenes. Santiago de Chile: Ediciones Metales Pesados.

Donoso Macaya, A. 2012. "Arte, documento y fotografía: prolegómenos para una reformulación del campo fotográfico en Chile (1977-1998), en AISTHESIS 52: 407-424

Museo de la Memoria y los Derechos Humanos. 2013. Fragmentos / Memorias / Imágenes. A 40 años del golpe. Santiago: Ograma impresores.

Fresard Moreno, D. 2007. Antonio Quintana 1904-1972. Santiago: Pehuén Editores.

Guzmán Campos, P. 2010. Chile en la retina. Fotografías 1957-1973. Santiago: LOM Ediciones.

Gamarnik, C. 2012. "Fotografía y dictaduras: estrategias comparadas entre Chile, Uruguay y Argentina." en Nuevo Mundo Mundos Nuevos, Images, mémoires et sons. Disponible en: http://nuevomundo.revues.org/63127 ;DOI: 10.4000/ nuevomundo.63127

Hoppe, A., López, H., Montecino, M., y Pérez, C. 2013. Chile
1973-1990. La dictadura de Pinochet. Santiago: LOM Ediciones. Jagare, K. 2009. Érase una vez 1971-1972. Santiago: Andros Impresores.

Leiva Quijada, G. 2008. AFI. Multitudes en sombras. Santiago: Ocho libro editores.

2012. Sergio Larraín. Biografía / estética / fotografía.

Santiago: Ediciones Metales Pesados.

Leiva Quijada, G. Errázuriz, L. H. 2012. El golpe estético Dictadura militar en Chile 1973-1989. Santiago: Ocho libro ediciones.

Marinello, J.D. 2015. Punto Ciego. Santiago: Pehuén Editores.

Meiselas, S. 1990. Chile from within. London / New York: Norton

Montealegre, M. 2011. No me olvido. Chile 1954-1968. Santiago: Ocho libros editores.

Montecino, M. 2011. Irredimible. Diario/1973. Santiago: Ocho libros editores.

Montecino, M. 2013. Marcelo Montecino 50 años. Santiago: Pehuén Ediciones.

Montecino, M. 2014. Las calles de las penas. Santiago: LOM Ediciones.

Orrego Standen, P. 2013. Fotografía, Historia y Memoria. Presencia de una ausencia: La fotografía de los detenidos desaparecidos en cuatro momentos. Santiago: Pontificia Universidad Católica. Tesis para optar al grado académico de Magíster.

Poirot, L. 2011. Identidad fortuita. Santiago: LOM Ediciones.

Peris Blanes, J. "De la prueba documental a la evocación subjetiva. Usos de la fotografía en las publicaciones sobre la represión chilena", en Paisajes de pensamiento contemporáneo 30: 85-97.

Poirot, L. 2013. La sopa derramada 1969-1973. Santiago: Museo de la Memoria y los Derechos Humanos.

Ramírez L. 2015. "La desubjetivización del testimonio", en Lineas de la no libertad. Madrid: Universidad Autónoma de México: 50 - 54.

Richard, N. 2007. Fracturas de la memoria. Arte y pensamiento 
crítico. Buenos Aires: Siglo XXI.

Rodríguez, Villegas H, T S. Salgado, H J. Fermandois, y Myriam Duchens. 2010. Chile a Través De La Fotografía, 18472010. Madrid: Fundación Mapfre.

Rojas, M., González L. y Fonseca M. 2012. Visible / Invisible. Tres fotógrafas durante la dictadura militar en Chile. Santiago: Ocho libros editores.

Rojas de Negri, R. 2013. Un exilio sin retorno. Santiago: LOM Ediciones.
Sánchez, G. 2001. La caravana de la muerte: Las víctimas de Pinochet. Barcelona: Editorial Contrapunto: Art Blume.

Secretaría General del Gobierno. 1973. El libro blanco del cambio de gobierno en Chile. Santiago : Editorial Lord Cochrane. Sire, A. 2013. Sergio Larrain. Paris: Éditions Xavier Barral.

Sontag, S. 2010. Ante el dolor de los demás. Barcelona: Debolsillo. Edición Kindle.

Wessing, K. 2011. Fotografía. El arte de visibilizar la pregunta. Santiago: LOM Ediciones. 